
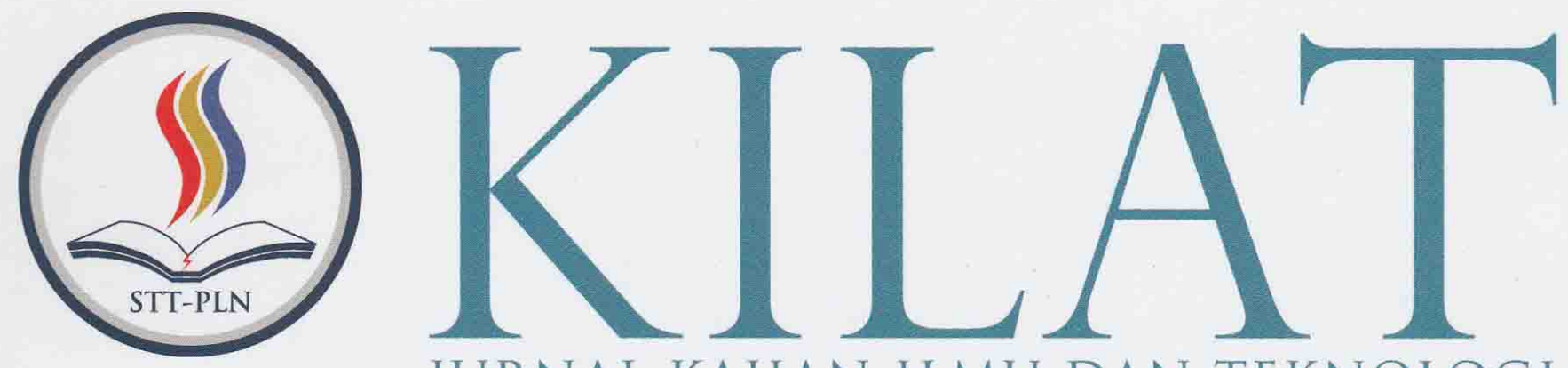
JURNAL KAJIAN ILMU DAN TEKNOLOGI

Dine Tiara Kusuma:

M. Yoga Distra Sudirman: Yessy Fitriani

Emillia; Yuliansyah

Rosida Nur Aziza; Dhzillan Dzhalila

Ranti Hidayawanti

Dewi Arianti Wulandari; Hendra Jatnika; Yudhy S. Purwanto

Rr. Mekar Ageng Kinasti; Endah Lestari; Devita Mayasari

Faisal Piliang

Mauludi Manfaluthy

Pauzi Hasan; Peby Wahyu Purnawan

Rahmi Amir: Baginda Oloan Lubis

Sabar Hanadwiputra; Subandri

Ndaru Ruseno; Satria
PENDEKATAN METODE ALTMAN Z-SCORE DALAM PENENTUAN INSENTIF BONUS PEGAWAI

METODE YURIDIS PENGELOLAAN SAMPAH RUMAH TANGGA DAN SAMPAH SEJENIS DI STT-PLN

METODE KUANTITATIF DENGAN PENDEKATAN KLASIK PADA APLIKASI ANALISIS BUTIR SOAL SEBAGAI MEDIA EVALUASI PENENTUAN SOAL YANG BERKUALITAS

UPAYA TERTIB LISTRIK TERHADAP INSTALATIR KABEL DI DAERAH PADAT PENDUDUK (STUDY KASUS KEC. TAMBORA)

RANCANG BANGUN APLIKASI CLUSTERING DATA MINING MENGGUNAKAN METODE K-MEANS DAN K-MODES

POTENSI PEMANFAATAN LIMBAH PEMBAKARAN BATUBARA (BOTTOM ASH) PADA PLTU SEBAGAI MEDIA TANAM DALAM UPAYA MENGURANGI PENCEMARAN LINGKUNGAN

PEMILIHAN PERANGKAT LUNAK PEMINDAHAN BERKAS DALAM MENINGKATKAN PEMANFAATAN TELEPON PINTAR

PEMANFAATAN RADIASI ENERGI TEGANGAN 150 KV UNTUK LAMPU LED PENERANGAN JALAN

KAJIAN PERBANDINGAN PERFORMANSI ROUTING PROTOCOL RIPNG, OSPFV3 DAN EIGRPVG PADA JARINGAN IPV6

PERANCANGAN PROGRAM PENGELOLAAN DATA KEUANGAN PASIEN RAWAT JALAN BPJS PADA RUMAH SAKIT GRAHA JUANDA BEKASI

ANALISA DAN IMPLEMENTASI VTP DENGAN ETHERCHANNEL TYPE LACP

PENGEMBANGAN RANCANG BANGUN SISTEM KESISWAAN DENGAN MENGGUNAKAN FRAMEWORK MVC

(MODEL VIEW CONTROLLER)

\begin{tabular}{|l|l|l|l|l|l|}
\hline KILAT & VOL.7 & NO.1 & HAL. 1 - 90 & APRIL 2018 & ISSN 2089 - 1245 \\
\hline
\end{tabular}




\title{
METODE YURIDIS PENGELOLAAN SAMPAH RUMAH TANGGA DAN SAMPAH SEJENIS DI STT-PLN
}

\author{
Emillia $^{1}$; Yuliansyah ${ }^{2}$ \\ Jurusan Teknik Mesin STT-PLN Jakarta \\ Email : emilliakobiarek@gmail.com ${ }^{1}$, yansyah62@gmail.com²
}

\begin{abstract}
This paper uses exploratory research to conduct research in Final Disposal Site and Waste Management STT-PLN Jakarta. Keep questioning and interviewing students and officers at Final Disposal. The research team is also on reference books, research results and national journals and legislation discussing with waste management. The problem in this paper is dilipatbelangi with increasingly creating the number of Indonesian population until in 2011 reached 259,940,857 people who cause people who do business to produce works of real standard of living that has a positive and negative impact. Negative impact on the environment is very prominent problem of pollution. The most common contamination is garbage. Therefore, agar-agar can help the tasks in the necessary and very high effective difficulties in handling waste and vice versa, the efforts required will produce even more. To achieve the things necessary for proper ways and technologies and from waste sources. In addition, it also needs legal aspects to be a Guidebook-Regulations related to waste and the environment in order to cope with environmental pollution caused by garbage.
\end{abstract}

Keywords: Waste, Management, Utilization, Law, STT-PLN

\begin{abstract}
Abstrak
Tulisan ini menggunakan penelitian yang bersifat eksplanatoris melakukan obsevasi lapangan di Tempat Pembuangan Akhir dan Pengelolaan Sampah STT-PLN Jakarta. Melakukan tanya jawab dan interview pada mahasiswa dan petugas di Tempat Pembuangan Akhir. Tim peneliti juga mempelajari buku-buku acuan, hasil penelitian dan jurnal Nasional dan peraturan perundangan yang berkaitan dengan pengelolaan sampah. Permasalahan dalam tulisan ini dilatarbelakangi dengan semakin meningkatnya jumlah penduduk Indonesia hingga pada tahun 2011 mencapai 259.940.857 jiwa yang menyebabkan kemiskinan yang mendorong pemerintah untuk melakukan usaha pembangunan secara besar-besaran untuk meningkatkan standar kehidupan warganegaranya tersebut yang memiliki dampak positif dan negatif. Dampak negatif terhadap lingkungan yang sangat menonjol adalah masalah pencemaran. Pencemaran yang paling umum adalah masalah sampah. Oleh karena itu, agar dapat membantu tugas pemerintah dalam pengelolaan sampah diperlukan tingkat efektifitas dan efisiensi yang tinggi dalam penanganan sampah dan sekaligus disertai upaya pemanfaatannya sehingga diharapkan mempunyai keuntungan berupa nilai tambah. Untuk mencapai hal tersebut diperlukan pemilihan cara dan teknologi yang tepat dan partisipasi aktif dari masyarakat sumber sampah berasal. Di samping itu juga perlu aspek hukum untuk sebagai pedoman berupa peraturan-peraturan yang berkaitan dengan sampah dan lingkungan hidup demi menanggulangi pencemaran lingkungan yang diakibatkan oleh sampah.
\end{abstract}

Kata kunci : sampah, pengelolaan, pemanfaatan, hukum, STT-PLN

\section{PENDAHULUAN}

Indonesia merupakan salah satu negara yang memiliki penduduk yang sangat besar dan memiliki kecenderungan meningkat dari waktu ke waktu. Berdasarkan data Badan Pusat Statistik selama 30 tahun terakhir jumlah penduduk Indonesia meningkat hampir dua kali lipat, yaitu 147,49 juta jiwa pada tahun 1980 menjadi 179,37 juta jiwa pada tahun 1990 dan pada tahun 2000 bertambah mencapai 206,26 juta jiwa. Angka tersebut terus mengalami peningkatan dan mencapai 218,86 juta jiwa pada tahun 2005 hingga peningkatan itu terus meningkat hingga pada tahun 2011 mencapai 259.940.857 jiwa. Hal tersebut akan mengakibatkan semakin besarnya volume sampah yang dihasilkan oleh manusia setiap tahunnya. Jumlah penduduk yang terus meningkat akan mengakibatkan kemampuan sumber daya alam seperti air dan udara untuk menyerap limbah yang diakibatkan oleh aktivitas manusia menjadi menurun. Kenaikan jumlah penduduk tersebut juga akan meningkatkan volume sampah yang dihasilkan terutama di kotakota besar yang ada di Indonesia. Di samping itu dengan semakin meningkatnya jumlah penduduk di Indonesia berdampak pada segi pendapatan atau penghasilan. Kemiskinan digambarkan sebagai kurangnya pandapatan atau penghasilan untuk memenuhi kebutuhan hidup pokok. Menurut Badan Pusat Statistik salah satu kriteria keluarga miskin adalah pendapatan keluarga rendah. Garis kemiskinan dipergunakan sebagai suatu batas untuk menentukan miskin tidaknya seseorang. Badan Pusat Statistik telah menggunakan batas garis kemiskinan yang baru. Sejak Maret 2011, batas garis kemiskinan berdasarkan Badan Pusat Statistik adalah pengeluaran Rp 233.740 per bulan 
atau naik 10,39 persen dibandingkan dengan batas garis kemiskinan Maret 2010 sebesar Rp 211.726. Sedangkan Bank Dunia pada tahun 2001 untuk standar internasional memberikan batas garis kemiskinan yang lebih tinggi dari standar-standar lainnya yaitu dengan pendapatan perkapita sebesar US\$ 275 per tahun atau 2 dollar per hari.

Sampah pada dasarnya merupakan suatu bahan yang terbuang atau dibuang dari suatu sumber hasil aktivitas manusia maupun prosesproses alam yang tidak mempunyai nilai ekonomi, bahkan dapat mempunyai nilai ekonomi yang negatif karena dalam penanganannya baik untuk membuang atau membersihkannya memerlukan biaya yang cukup besar. Setiap aktivitas manusia pasti menghasilkan buangan atau sampah. Jumlah atau volume sampah sebanding dengan tingkat konsumsi kita terhadap barang atau material yang kita gunakan sehari-hari. Demikian juga dengan jenis sampah sangat tergantung dari jenis material yang dikonsumsi. Oleh karena itu pengelolaan sampah tidak bisa lepas juga dari "pengelolaan" gaya hidup masyarakat. Oleh sebab itu penanggulangan yang serius sangat dibutuhkan untuk mengatasi produksi sampah yang cukup besar tersebut. Hal ini dikarenakan, sampah merupakan salah satu penyebab terjadinya pencemaran lingkungan yang pada akhirnya akan menyebabkan kerusakan lingkungan. Pengelolaan sampah yang tampak selama ini hanya dilakukan secara konvensional yaitu pengumpulan, pengangkutan dan pembuangan akhir di Tempat Pembuangan Akhir (TPA). Keterbatasan lahan menjadi permasalahan bagi pembukaan TPA baru, sehingga saat ini kondisi TPA yang sudah ada telah mengalami daya tampung yang berlebih. Diperkirakan paling banyak hanya sekitar $65 \%$ sampah yang dapat terangkut ke TPA oleh institusi yang bertanggung jawab atas masalah sampah dan kebersihan.

\section{METODOLOGI PENELITIAN}

Seperti yang telah diketahui bahwa supaya penyusunan tulisan ilmiah dapat dipertanggung jawabkan kebenarannya, maka setiap tulisan ilmiah harus didukung dengan adanya penelitian. Penelitian lapangan dilakukan di Tempat Pembuangan Akhir (TPA) dan Tempat Pembuangan Sampah (TPS) STT-PLN Jakarta. Observasi yang dilakukan dalam penelitian kualitatif sering disebut sebagai "Observasi Partisipatif". Observasi langsung ini akan dilakukan dengan cara formal dan informal untuk mengamati berbagai kegiatan dan peristiwa yang terjadi pada kegiatan pengelolaan sampah di TPA dan TPS di STT-PLN, berikut dengan kondisi sosial dan lingkungan sekitarnya. Tim peneliti juga melakukan melakukan wawancara. Teknik wawancara yang digunakan adalah dengan tidak terstruktur atau yang disebut dengan wawancara mendalam (indepth interviewing). Wawancara ini bersifat lentur dan terbuka, tidak terstruktur ketat, tidak dalam suasana formal, dan bisa dilakukan berulang pada informan yang sama. Pertanyaan yang diajukan bisa semakin terfokus sehingga informasi yang bisa dikumpulkan semakin rinci dan mendalam. Kelonggaran dan kelenturan cara ini akan mampu mengorek kejujuran informan untuk memberikan informasi yang sebenarnya, terutama yang berkaitan dengan perasaan, sikap dan pandangan mereka terhadap kegiatan pengelolaan sampah di TPA dan TPS STT-PLN. Oleh karena itu dalam penelitian diharapkan dapat mengungkapkan juga kendalakendala atau hambatan-hambatan yang ada di Tempat Pembuangan Akhir dan proses pengelolaan sampah. Penelitian ini bersifat eksplanatoris, yaitu berusaha menerangkan dan menguji serta bertujuan untuk mencari hubungan-hubungan yang ada dari berbagai fenomena yang diteliti yang berkaitan dengan pokok permasalahan. Penelitian ini menggunakan data primer dan data sekunder yang bersumber pada bahan hukum primer, sekunder dan tersier. Sedangkan penelitian hukum dilakukan secara normatif terhadap peraturan perundang-undangan yang berlaku saat ini. Metode analisa data yang dipergunakan penulis adalah memakai metode pendekatan secara kualitatif. Metode ini menggunakan unsur-unsur kemampuan untuk mengajukan pertanyaan-pertanyaan tentang fenomena-fenomena yang ditemui dalam kegiatan pengelolaan sampah di STT-PLN Jakarta serta kemampuan untuk mencari jawaban atas pertanyaan-pertanyaan tersebut dan juga kemampuan untuk mempelajari jenis-jenis informasi yang bermanfaat guna menjawab berbagai pertanyaan yang berbeda, sehingga mampu menyimpulkan informasi untuk suatu analisa yang bermakna. Informasi yang terkumpul berupa hasil observasi lapangan dan observasi kepustakaan. Setelah data terkumpul kemudian akan disusun menjadi laporan penulisan hasil penelitian yang sistimatis.

\section{HASIL DAN PEMBAHASAN}

Sekolah Tinggi Teknik PLN terletak di Jakarta Barat yang memiliki area yang cukup luas yang terdiri atas beberapa bangunan yang meliputi gedung utama yang terdiri atas 12 lantai dan dilengkapi oleh 2 gedung tambahan berlantai 4 , sebuah mesjid dan fasilitas kafetaria serta dilengkapi dengan lapangan olah raga dan fasilitas halaman parkir kendaraan yang luas. STT-PLN memiliki jumlah mahasiswa sebesar \pm 4.000 orang mahasiswa dengan jumlah tenaga kerja atau pegawai sebesar \pm 250 orang. Berdasarkan keadaan STT-PLN tersebut maka memiliki potensi sebagai penghasil sampah yang cukup besar. Berdasarkan penelitian sampah-sampah yang dihasilkan STT-PLN dan perumahan sekitar STTPLN yang ikut membuang sampahnya ke STT-PLN dapat dilihat di dalam tabel yang akan disajikan berikut ini yaitu sebagai berikut :

Tabel 1. Jenis Sampah STT-PLN

\begin{tabular}{|c|c|c|}
\hline NO. & $\begin{array}{c}\text { PENGGOLONGAN } \\
\text { SAMPAH }\end{array}$ & \multicolumn{1}{|c|}{ JENIS SAMPAH } \\
\hline 1. & Sampah kering & $\begin{array}{l}\text { Plastik berupa kemasan } \\
\text { pembungkus berbagai macam } \\
\text { makanan atau minuman, } \\
\text { kardus, kertas baik berupa } \\
\text { tisu, kertas untuk mengemas } \\
\text { makanan maupun berbagai } \\
\text { macam kertas yang digunakan } \\
\text { dalam kegiatan perkantoran }\end{array}$ \\
\hline
\end{tabular}




\begin{tabular}{|c|l|l|}
\hline & & $\begin{array}{l}\text { maupun perkuliahan dan alat- } \\
\text { alat tulis yang tidak terpakai } \\
\text { termasuk juga styrofoam baik } \\
\text { sebagai kemasan } \\
\text { pembungkus barang-barang } \\
\text { elektronik maupun } \\
\text { pembungkus makanan. }\end{array}$ \\
\hline 2. & Sampah basah & $\begin{array}{l}\text { Daun, rumput dan batang } \\
\text { pohon, sisa-sisa makanan dan } \\
\text { minuman seperti nasi dan } \\
\text { sayur, tulang-tulang, mie, } \\
\text { gorengan, atau jajanan }\end{array}$ \\
\hline 3. & Sampah balokan & $\begin{array}{l}\text { Meja, kursi yang tidak terpakai } \\
\text { atau peralatan elektronik, } \\
\text { kabel dan tembaga atau } \\
\text { logam yang sudah tidak bisa } \\
\text { dipergunakan lagi. }\end{array}$ \\
\hline
\end{tabular}

Agar lebih jelas dapat dilihat dalam gambar tempat pembuangan sampah yang yang ada di STT-PLN, yaitu sebagai berikut :

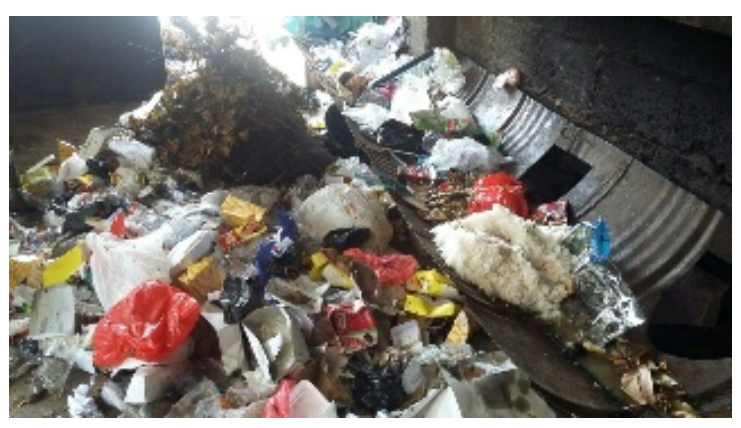

Gambar 1. Tempat Pembuangan Sampah STT-PLN

Sampah-sampah yang yang berasal dari STTPLN dan perumahan yang berada di sekitar STTPLN tersebut kemudian akan dikumpulkan di tempat pembuangan akhir yang juga merupakan tempat pengelolaan sampah. Berdasarkan penelitian volume sampah yang ditampung di tempat pembuangan akhir ini dapat dilihat secara terperinci dalam tabel yang disajikan di bawah ini yaitu sebagai berikut :

Tabel 2. Volume Sampah STT-PLN

\begin{tabular}{|c|l|l|}
\hline No. & Jenis Aktivitas & Volume Sampah \\
\hline 1. & $\begin{array}{l}\text { Hari kerja disertai } \\
\text { dengan kegiatan } \\
\text { perkuliahan }\end{array}$ & $\begin{array}{l}1 \mathrm{~m}^{3} \text { yang dikemas ke } \\
\text { dalam kantong plastik } \\
\text { sampah berwarna hitam } \\
\text { dengan ukuran } 90 \mathrm{~cm} \times 120 \\
\mathrm{~cm} \text { sebanyak } 20 \text { kantong. }\end{array}$ \\
\hline 2. & $\begin{array}{l}\text { Hari kerja namun tidak } \\
\text { ada kegiatan } \\
\text { perkuliahan }\end{array}$ & $\begin{array}{l}\text { 0,5 } \mathrm{m}^{3} \text { yang dikemas ke } \\
\text { dalam kantong plastik } \\
\text { sampah berwarna hitam } \\
\text { dengan ukuran } 90 \mathrm{~cm} \times 120 \\
\text { cm sebanyak } 10 \text { kantong. }\end{array}$ \\
\hline 3. & $\begin{array}{l}\text { Hari libur week end } \\
\text { namun ada kegiatan } \\
\text { extra mahasiswa yang } \\
\text { sifatnya tidak periodik } \\
\text { atau waktu tertentu } \\
\text { saja }\end{array}$ & $\begin{array}{l}0,5 \mathrm{~m}^{3} \text { yang dikemas ke } \\
\text { dalam kantong plastik } \\
\text { sampah berwarna hitam } \\
\text { dengan ukuran } 90 \mathrm{~cm} \times 120 \\
\mathrm{~cm} \text { sebanyak } 10 \text { kantong. }\end{array}$ \\
\hline 4. & $\begin{array}{l}\text { Hari libur week end } \\
\text { namun sama sekali } \\
\text { tidak ada kegiatan } \\
\text { extra mahasiswa } \\
\text { apapun dan hari libur } \\
\text { nasional }\end{array}$ & $\begin{array}{l}\text { 0,1 } \mathrm{m}^{3} \text { yang dikemas ke } \\
\text { dalam kantong plastik } \\
\text { sampah berwarna hitam } \\
\text { dengan ukuran } 90 \mathrm{~cm} \times 120 \\
\mathrm{~cm} \text { sebanyak } 2 \text { kantong. }\end{array}$ \\
\hline
\end{tabular}

Berdasarkan tabel yang disajikan di atas terlihat jelas bahwa jumlah volume sampah yang terbesar adalah berasal dari lingkup internal STTPLN, sedangkan dari perumahan yang berada di lingkungan STT-PLN tidak begitu banyak yang membuang sampahnya ke tempat pembuangan sampah di STT-PLN, sehingga dengan demikian dapat disimpulkan bahwa memang STT-PLN memiliki potensi menghasilkan sampah yang cukup besar. Selanjutnya sampah-sampah yang terkumpul di tempat pembuangan sampah STT-PLN itu akan dipilah-pilah dan dibagi menjadi dua jenis yaitu sebagai berikut :

1. Sampah organik

Sampah organik adalah daun, rumput dan batang pohon, sisa-sisa makanan dan minuman seperti nasi dan sayur, tulangtulang, mie, gorengan, atau jajanan maupun aktivitas memasak dan aktivitas makan. Sifat dari sampah organik sangat mudah membusuk dan memiliki kadar air yang tinggi.

2. Sampah non organik

Sampah non organik adalah sampah yang memiliki ciri tidak mudah membusuk. Sampah jenis ini dibagi menjadi dua yaitu sampah non organik yang mudah terbakar, yaitu seperti kemasan pembungkus berbagai macam makanan atau minuman, kardus, kertas baik berupa tisu, kertas untuk mengemas makanan maupun berbagai macam kertas yang digunakan dalam kegiatan perkantoran maupun maupun perkuliahan dan alat-alat tulis yang tidak terpakai, meja dan kursi kayu bekas. Sedangkan untuk sampah non organik yang tidak mudah terbakar adalah pecahan kaca, styrofoam, kabel dan tembaga atau logam yang sudah tidak bisa dipergunakan lagi.

Sampah-sampah yang terkumpul ini kemudian dikelola melalui cara pembuatan kompos di tempat pembuangan akhir sampah di STT-PLN. Secara umum kompos merupakan istilah untuk pupuk organik buatan manusia yang dibuat melalui proses pembusukan sisa-sisa mahkluk hidup. Proses ini disebut dekomposisi atau fermentasi. Kompos yang baik adalah kompos yang mengalami pelapukan dengan ciri-ciri warna yang berbeda dengan bahan pembentuknya, tidak berbau kadar air rendah dan mempunyai suhu ruang. Manfaat kompos antara lain adalah sebagai berikut :

a. Menyediakan unsur hara mikro bagi tanaman.

b. Menggemburkan tanah.

c. Memperbaiki struktur dan tekstur tanah.

d. Meningkatkan porositas, serasi dan komposisi mikroorganisme tanah.

e. Meningkatkan daya ikat tanah terhadap air.

f. Memudahkan pertumbuhan akar tanaman.

g. Menyimpan air tanah lebih lama.

h. Bersifat multi lahan karena dapat digunakan di lahan pertanian, perkebunan, reklamasi lahan kritis, maupun padang golf.

Kompos yang dibuat di STT-PLN dilakukan dengan cara melalui pembuatan briket, yaitu dengan cara fermentasi atau peuyemnisasi dimasukkan ke dalam keranjang yang terbuat dari bambu berukuran 1,3 $\mathrm{m}^{2}$ kemudian dimasukan sampah sebanyak $20 \mathrm{~cm}^{3}$ yang disirami dengan air lindi. Air lindi ini dihasilkan dari Biodigester yang berasal dari sampah organik. Biodisgester dapat 
dilihat dalam gambar yang disajikan berikut ini, yaitu sebagai berikut :

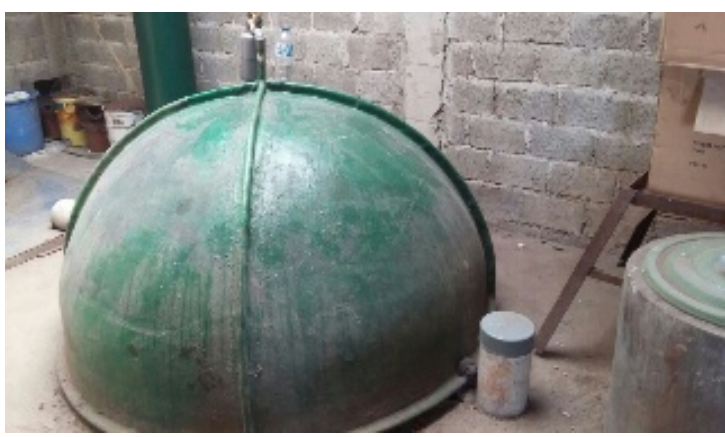

Gambar 2. Biodisgester

Selanjutnya dalam proses fermentasi atau peuyemnisasi ini sampah akan didiamkan selama 10 (sepuluh) hari untuk lebih jelasnya dapat dilihat dalam gambar yang disajikan berikut ini, yaitu sebagai berikut :

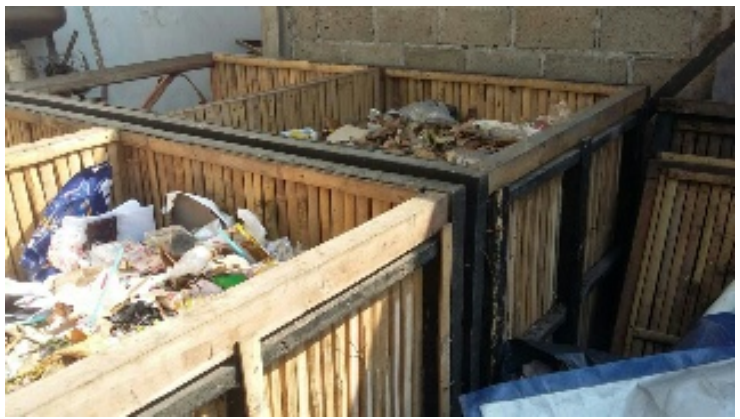

Gambar 3. Fermentasi Sampah

Setelah 10 (sepuluh) hari difermentasi atau dipeuyemnisasi sampah ini akan dibongkar atau dipanen kemudian proses selanjutnya akan dirajang dan digiling menggunakan Mesin Choper atau Klaser. Gambar Mesin Choper atau Klaser dapat dilihat sebagai berikut :

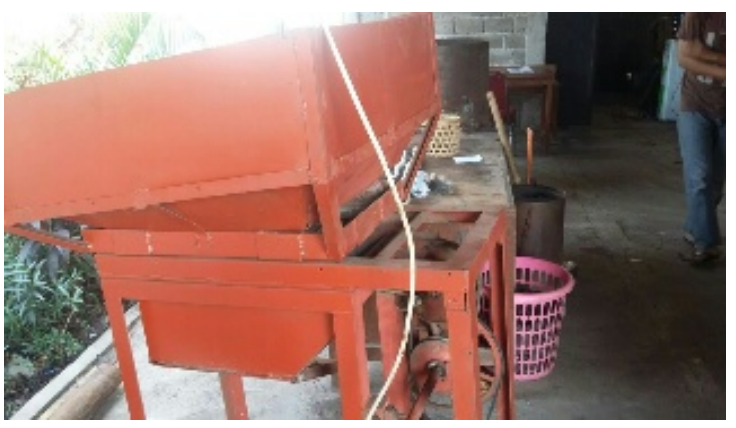

Gambar 4. Mesin Choper atau Klaser

Hasil dari perajangan dan penggilingan sampah menghasilkan sampah yang masih kasar Sampah kasar ini kemudian diayak sampai menjadi halus, untuk lebih jelasnya dapat dilihat dalam tiga gambar berikut ini, yaitu :

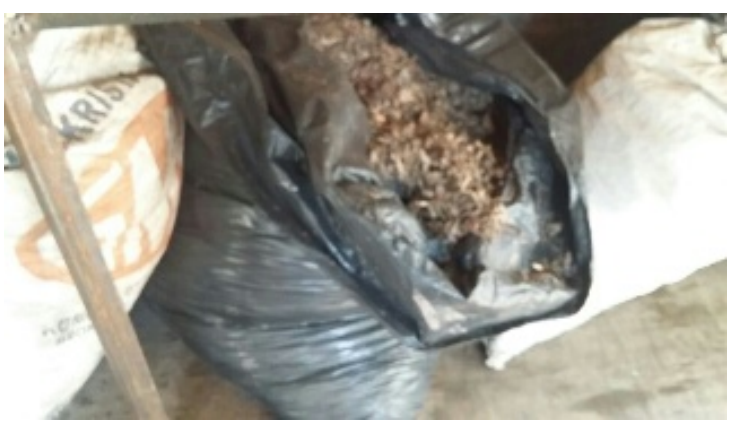

Gambar 5. Hasil Sampah Kasar

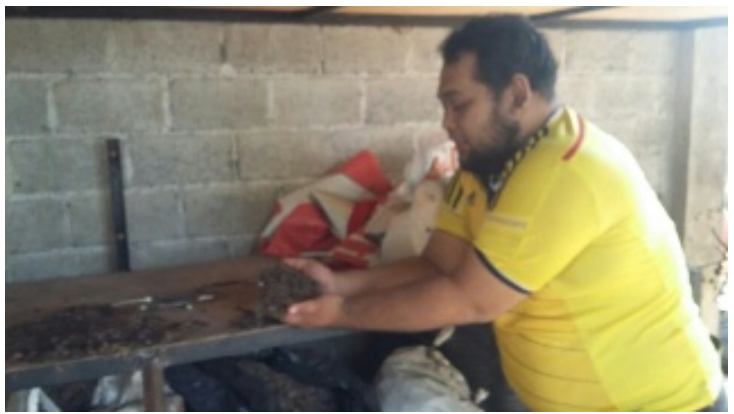

Gambar 6. Pengayakan Sampah

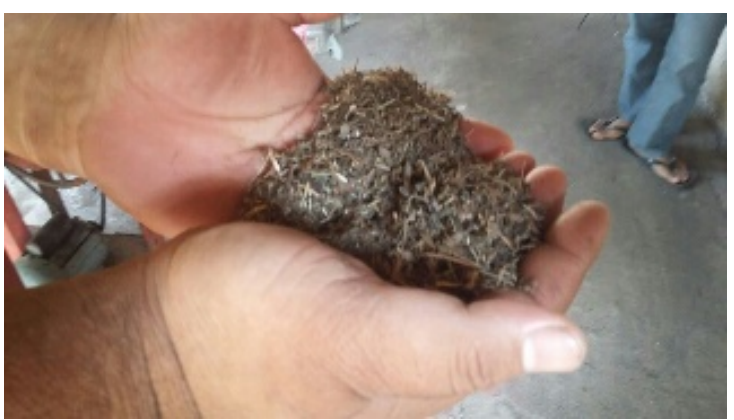

Gambar 7. Hasil Sampah Halus

Selanjutnya hasil akhir berupa sampah halus akan dibuat menjadi briket. Skema proses pengelolaan sampah di STT-PLN menjadi briket dapat dilihat dalam diagram blok alur berikut ini, yaitu sebagai berikut :

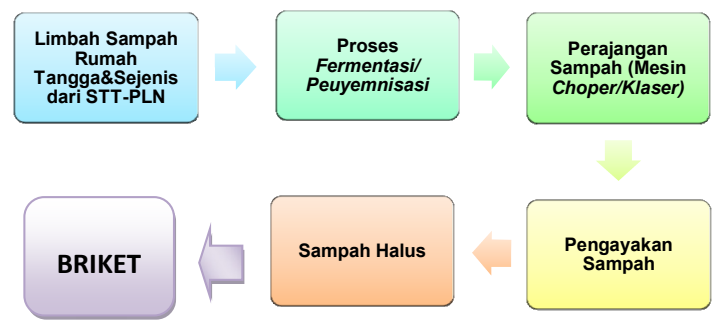

Gambar 8. Blok Alur Produksi Briket STT-PLN

Analisa Terhadap Pertaturan Perundangan Terhadap Pengelolaan Sampah Rumah Tangga dan Sampah

Problematika mengenai sampah merupakan hal yang sangat penting. Sampah merupakan hal yang berkaitan dengan sampah dan perilaku 
masyarakat terutama di wilayah perkotaan. Oleh karena itu perlu pengelolaan sampah yang benar sesuai dengan peraturan perundangan yang ada. Permasalahan sampah menjadi masalah yang penting di berbagai wilayah perkotaan khususnya yang padat penduduk. Hal tersebut dikarenakan sebagian besar masyarakat memandang bahwa sampah merupakan sisa dari penggunaan suatu barang baik organik maupun non organik yang tidak dapat dimanfaatkan. Sehingga masyarakat dalam mengelola sampah masih bertumpu pada pendekatan akhir (end of pipe), sampah dikumpulkan, diangkut dan dibuang ke tempat pemrosesan akhir sampah. Padahal timbunan sampah dengan volume yang besar di lokasi tempat pemoresan akhir sampah berpotensi melepas gas metan $(\mathrm{CH} 4)$ yang dapat meningkatkan emisi gas rumah kaca dan memberikan kontribusi terhadap pemanasan global. Agar timbunan sampah dapat terurai melalui proses alam diperlukan jangka waktu yang lama dan penanganan dengan biaya yang besar. Di dalam pengelolaan sampah pemerintah pusat dan pemerintah daerah memerlukan kebijakan dalam bidang regulasi yang didasarkan pada peraturan-peraturan tingkat nasional maupun daerah.

\section{Pasal $28 \mathrm{H}$ ayat 1 Undang-Undang Dasar Negara Republik Indonesia Tahun 1945.}

Pasal $28 \mathrm{H}$ ayat 1 UUD 1945 tersebut berbunyi sebagai berikut : "Setiap orang berhak hidup sejahtera lahir dan batin, bertempat tinggal dan mendapatkan lingkungan hidup yang baik dan sehat serta berhak memperoleh pelayanan kesehatan." Ketentuan di atas menjadi landasan bahwa lingkungan hidup harus menjadi point penting dalam konteks perlindungan hak asasi manusia di Indonesia dan penegakan hukum menjadi element perlindungan hak asasi manusia. Penegakan hukum sendiri menurut Prof. Dr. Jimly Asshiddiqie, $\mathrm{SH}$ adalah "Proses dilakukannya upaya untuk tegaknya atau berfungsinya normanorma hukum secara nyata sebagai pedoman perilaku dalam lalu lintas atau hubungan-hubungan hukum dalam kehidupan bermasyarakat dan bernegara." Apabila dikaitkan dengan lingkungan hidup, maka proses penegakan hukum berarti tegaknya norma-norma hukum dalam upaya perlindungan lingkungan hidup. Dalam upaya tegaknya perlindungan hukum itu, maka regulasi hukum lingkungan hidup tidak bisa dilupakan dalam upaya penegakan hukum lingkungan itu. Oleh karena itu ketentuan ini memberikan hak pada setiap orang untuk mendapatkan lingkungan hidup yang baik dan sehat. Pasal tersebut memberikan konsekuensi bahwa pemerintah wajib memberikan pelayanan publik dalam pengelolaan sampah. Hal ini memberikan konsekuensi hukum bahwa pemerintah merupakan pihak yang berwenang dan bertanggung jawab di bidang pengelolaan sampah. Meskipun pengelolaan sampah merupakan kewajiban pemerintah akan tetapi hal tersebut juga dapat melibatkan dunia usaha dan masyarakat yang bergerak di bidang persampahan. Dalam rangka pengelolaan sampah secara terpadu dan komperhensif pemenuhan hak dan kewajiban masyarakat serta tugas dan wewenang pemerintah daerah untuk pemenuhan pelayanan publik diperlukan payung hukum dalam bentuk undangundang. Pengaturan hukum pengelolaan sampah dalam Undang-Undang Dasar ini berdasarkan asas tanggung jawab, asas berkelanjutan, asas manfaat, asas keadilan, asas kesadaran, asas kebersamaan, asas keselamatan, asas, asas keamanan dan asas nilai ekonomi.

Undang-Undang No. 32 Tahun 2009 Tentang Perlindungan dan Pengelolaan Lingkungan Hidup.

Ketentuan dalam undang-undang tersebut di atas yang dikaitkan dengan masalah sampah dapat ditemui di dalam tiga pasal, yaitu pasal 2, pasal 3 dan pasal 13. Di dalam ketentuan lingkungan hidup tersebut menyatakan bahwa kegiatan pembangunan juga mengandung risiko terjadinya pencemaran dan kerusakan lingkungan. Kondisi ini dapat mengakibatkan daya dukung, daya tampung dan produktivitas lingkungan hidup menurun yang pada akhirnya menjadi beban sosial. Pemenuhan lingkungan hidup yang baik dan sehat merupakan hak asasi dan hak konstitusional bagi setiap warganegara Indonesia. Oleh karena itu pemerintah dan seluruh pemangku kepentingan berkewajiban untuk melakukan perlindungan dan pengelolaan lingkungan hidup dalam pelaksanaan pembangunan berkelanjutan agar lingkungan hidup Indonesia dapat tetap menjadi sumber dan penunjang hidup bagi rakyat Indonesia serta mahkluk hidup lain. Sehingga pengelolaan sampah yang baik dan benar merupakan wujud dari pemenuhan lingkungan hidup yang baik dan sehat. Berkaitan dengan pengelolaan sampah bagi pemerintah tidak dapat lepas dari asas-asas yang terdapat dalam pasal 2 UU PPLH yang diatur mengenai asas tanggung jawab negara, asas partisipatif, asas tata kelola pemerintahan yang baik dan asas otonomi daerah. Oleh karena itu pengelolaan sampah merupakan wujud tanggung jawab negara melalui pemerintah pusat dan pemerintah daerah. Di samping itu dibutuhkan pula partisipasi masyarakat untuk melakukan pengelolaannya.

\section{Undang-Undang No. 18 Tahun 2008 Tentang Pengelolaan sampah.}

UU No. 18 Tahun 2008 Tentang Pengelolaan Sampah didasarkan atas jumlah penduduk Indonesia yang besar dengan tingkat pertumbuhan yang tinggi mengakibatkan bertambahnya volume sampah. Di samping itu pola konsumsi masyarakat memberikan kontribusi dalam menimbulkan jenis sampah yang semakin beragam, antara lain sampah kemasan yang berbahaya dan/atau sulit diurai oleh proses alam semakin beragam. Substansi undang-undang ini yang terkait dengan langsung dengan pengelolaan sampah dapat ditemui di dalam tiga pasal, yaitu sebagai berikut :

a. Pasal 19 UU No. 18 Tahun 2008

Pasal 19 ini mengatur mengenai pengelolaan sampah rumah tangga dan sampah sejenis sampah rumah tangga. Pasal tersebut menyebutkan bahwa pengelolaan sampah rumah tangga dan sampah sejenis sampah rumah tangga terdiri atas pengurangan 
sampah dan penanganan sampah. Apabila dikaitkan dengan pengelolaan sampah yang ada di STT-PLN, maka proses pengelolaan sampah sudah berhasil mengurangi sampah secara mandiri dan sampah tersebut dirubah menjadi briket.

b. Pasal 20 UU No. 18 Tahun 2008

Di dalam pasal 20 ini pengurangan sampah yang dimaksud meliputi kegiatan :

1. Pembatasan timbunan sampah.

Sampah yang terkumpul di tempat pembuangan akhir STT-PLN tidak boleh dibiarkan menumpuk sampai melebihi kapasitas. Sampah ini harus segera dikelola setiap hari.

2. Pendaurulangan dan/atau pemanfaatan kembali sampah.

Sampah yang dikelola STT-PLN tersebut akan diproses kembali menjadi briket seperti yang disajikan dalam gambar di bawah ini yaitu sebagai berikut:

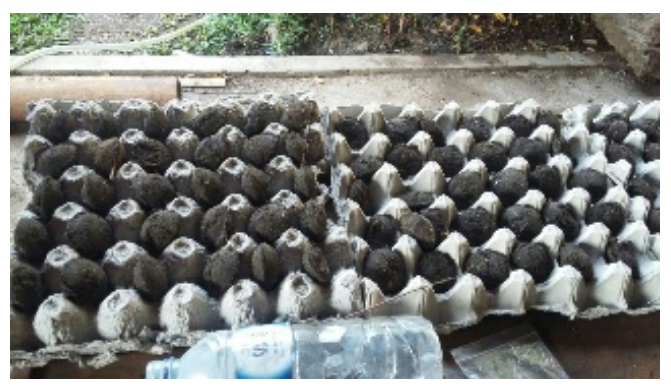

Gambar 8. Briket

Briket yang dihasilkan dari sampah STT-PLN adalah briket yang merupakan bahan bakar pengganti bahan bakar minyak yang paling murah dan dimungkinkan untuk dikembangkan secara massal dalam waktu relatif singkat mengingat teknologi yang digunakan relatif sederhana. Melalui briket sampah sebagai bahan bakar maka kita dapat menghemat penggunaan kayu sebagai hasil utama dari hutan. Selain itu penggunaan briket dapat menghemat pengeluaran biaya untuk membeli minyak tanah atau gas elpiji. Di samping itu dapat meningkatkan pendapatan masyarakat bila pembuatan briket sampah dikelola dengan baik karena merubah sampah menjadi barang yang bernilai guna. Ada empat macam briket yang dihasilkan di tempat pengelolaan sampah STT-PLN, yaitu sebagai berikut:

a. Briket biasa yang terbuat dari sampah organik yang dicampur dengan tepung kanji.

b. Briket campur dodol.

Dodol yang dimaksud di sini adalah sampah non organik seperti plastik, karet atau logam yang kemudian dipanaskan sampai meleleh menjadi cairan kental menyerupai dodol. Sampah organik yang sudah difermentasi atau peuyemnisasi kemudian dicampur dengan tepung kanji dan dodol sehingga terbentuk braket yang padat. c. Briket campur arang.

Sampah organik yang sudah di fermentasi atau peuyemnisasi kemudian dicampur dengan arang yang sudah dihaluskan dan tepung kanji sehingga terbentuk briket yang padat.

d. Briket campur kotoran manusia.

Sampah organik yang sudah di fermentasi atau peuyemnisasi kemudian dicampur dengan kotoran kering manusia dan tepung kanjji sehingga terbentuk briket yang padat.

c. Pasal 22 UU No. 8 Tahun 2008 yang mengatur bahwa pengelolaan sampah di STTPLN meliputi:

1. Pemilihan dalam bentuk pengelompokan dan pemisahan sampah sesuai dengan jenis, jumlah dan/atau sifat sampah.

2. Pengumpulan dalam bentuk pengambilan dan pemindahan dari sumber sampah ke tempat penampungan sementara atau atau ke tempat pengelolaan sampah mandiri.

3. Pengangkutan dalam bentuk membawa sampah dari sumber dan/atau dari tempat penampungan sampah sementara atau dari tempat penampungan sampah terpadu menuju ke tempat pemrosesan akhir.

4. Pengolahan dalam bentuk mengubah karakteristik, komposisi dan jumlah sampah.

5. Pemrosesan akhir sampah dalam bentuk pengembalian sampah dan/atau residu hasil pengolahan sebelumnya ke media lingkungan secara aman.

Ketentuan yang diatur dalam penyelenggaraan pengelolaan sampah dalam UU No. 18 Tahun 2008 Tentang Pengelolaan Sampah seharusnya mampu menangani permasalahan sampah di Indonesia. Sudah menjadi kebiasaan umum bahwa selama ini management sampah masih menerapkan masih menerapkan konsep Kumpul-Angkut-Buang (end of pipe). Sehingga dengan adamya undang-undang ini, maka management sampah telah mengadopsi konsep 3P atau 3R. Reduction (kurangi)-Reuse (gunakan kembali)-Recycling (daur ulang). Demikian halnya dengan paradigma sampah management sampah, bila selama ini menggunakan konsep konvensional yaitu sampah dianggap limbah sehingga dibuang yang memerlukan ongkos pembuangan dan pada akhirnya menjadi ancaman kesehatan bagi masyarakat. Maka sekarang digunakan paradigma baru yang menggunakan sampah sebagai sumber daya yang seharusnya diolah kembali sehingga menghasilkan pendapatan yang bermuara pada kesempatan terbukanya lapangan kerja baru dan kesempatan mendapatkan penghasilan baru.

Peraturan Pemerintah No. 81 Tahun 2012 Tentang Pengelolaan Sampah Rumah Tangga dan Sampah

Peraturan Pemerintah Nomor 81 Tahun 2012 tentang Pengelolaan Sampah Rumah Tangga dan Sampah Sejenis Sampah Rumah Tangga telah diundangkan pada tanggal 15 Oktober 2012. 
Peraturan pemerintah ini sangat penting sebagai peraturan pelaksanaan dari UU No. 18 Tahun 2008 tentang Pengelolaan Sampah, sekaligus memperkuat landasan hukum bagi penyelenggaraan pengelolaan sampah di Indonesia, khususnya di daerah. Terdapat beberapa muatan pokok yang penting yang diamanatkan oleh peraturan pemerintah ini, yaitu:

a. Memberikan landasan yang lebih kuat bagi pemerintah daerah dalam penyelenggaraan pengelolaan sampah yang berwawasan lingkungan dari berbagai aspek antara lain legal formal, manajemen, teknis operasional, pembiayaan, kelembagaan dan sumber daya manusia.

b. Memberikan kejelasan perihal pembagian tugas dan peran seluruh para pihak terkait dalam pengelolaan sampah mulai dari kementerian/lembaga di tingkat pusat, pemerintah provinsi, pemerintah kabupaten/kota, dunia usaha termasuk pengelola kawasan sampai masyarakat.

c. Memberikan landasan operasional bagi implementasi 3P atau 3R (reduce, reuse, recycle) dalam pengelolaan sampah menggantikan paradigma lama kumpulangkut-buang.

d. Memberikan landasan hukum yang kuat bagi pelibatan dunia usaha untuk turut bertanggungjawab dalam pengelolaan sampah sesuai dengan perannya.

Di samping itu ada tiga isu penting yang harus dicermati seiring disahkannya PP No. 81 Tahun 2012 ini, yaitu sebagai berikut :

a. Pertama, mulai tahun 2013 seluruh pemerintah kabupaten/kota harus mengubah sistem open dumping pada tempat pemrosesan akhir (TPA) menjadi berwawasan lingkungan.

b. Kedua, kalangan dunia usaha, dalam hal ini produsen, importir, distributor, dan retaile, bersama pemerintah harus segera merealisasikan penerapan extended producer responsibility (EPR) dalam pengelolaan sampah.

c. Ketiga, pengelola kawasan permukiman, kawasan industri, kawasan komersial, kawasan khusus, fasilitas umum, fasilitas sosial dan fasilitas lainnya, harus segera memilah, mengumpulkan dan mengolah sampah di masing-masing kawasan.

Akhir kata dengan PP No. 81 Tahun 2012 ini, akan mewujudkan pengelolaan sampah yang berwawasan lingkungan yang bertumpu pada penerapan 3P atau 3R seperti yang telah diulas di atas dalam rangka penghematan sumber daya alam, penghematan energi, pengembangan energi alternatif dari pengolahan sampah, perlindungan lingkungan dan pengendalian pencemaran

\section{KESIMPULAN DAN SARAN}

Setelah peneliti menguraikan bab demi bab, maka yang menjadi kesimpulan bahwa STT-PLN telah melakukan pengelolaan sampah mandiri secara tepat sesuai dengan peraturan perundangan yang berlaku yaitu :
1. Pasal $28 \mathrm{H}$ ayat 1 Undang-Undang Dasar Negara Republik Indonesia Tahun 1945.

2. Undang-Undang No. 32 Tahun 2009 Tentang Perlindungan dan Pengelolaan Lingkungan Hidup.

3. Undang-Undang No. 18 Tahun 2008 Tentang Pengelolaan sampah

4. Peraturan Pemerintah No. 81 Tahun 2012 Tentang Pengelolaan Sampah Rumah Tangga dan Sampah Sejenis Sampah Rumah Tangga.

Beberapa solusi pengelolaan sampah yang dilakukan STT-PLN sudah merujuk pada konsep pengelolaan sampah 3R, yaitu Reduction (kurangi)Reuse (gunakan kembali)-Recycling (daur ulang) dengan aplikasi sebagai berikut :

1. Pemilahan sampah dengan melakukan pembedaan tempat sampah.

2. Pembuatan komposting.

3. Melakukan daur ulang menjadi briket.

4. Mengembalikan tugas mahasiswa agar tidak menumpuk dan bisa digunakan lagi oleh mahasiswa tersebut.

Selanjutnya peneliti memberikan saran untuk mencapai hasil yang maksimal dalam pelaksanaan program pengelolaan sampah rumah tangga dan sampah sejenis secara mandiri dan terpadu, maka metode pengolahan sampah yang dilakukan STTPLN ini disosialisasikan kepada masyarakat lingkungan sekitar sehingga masyarakat merasa diajak dan ditanggapi dalam pengelolaan sampah rumah tangganya sendiri secara mandiri dan menumbuhkan kesadaran masyarakat akan pentingnya lingkungan hidup yang baik dan dan sehat.

\section{DAFTAR PUSTAKA}

Arikunto S. Sistem Pengelolaan Sampah Perkotaan. (Balai Pelatihan Air Bersih dan Penyehatan Lingkungan Permukiman).

Azwar, Azrul. Pengantar IImu Kesehatan Lingkungan. (Jakarta : Mutiara, 1983).

Bahar. Yul. H. Teknologi Penanganan dan Pemanfaatan Sampah. (Jakarta : PT. Waca Utama Pramaesti, 1986).

Daniel dan Hasan Purba. Teknologi Pemanfaatan Sampah Kota dan Peranan Pemulung Sampah. (Bandung : PPLH-ITB, 1985).

Sucipto CD. Teknologi Pengolahan Daur Ulang Sampah. (yogyakarta : Gosyen Publ., 2012).

Arief Fadnilah, Heri Sugianto, Kuncoro Hadi, Satriya Wahyu Firmandhani, Titien Woro, Murtini dan Edward Endrianto Pandelaki. "Kajian Pengelolaan Sampah Kampus Jurusan Arsitektur Fakultas Teknik Iniversitas Diponegoro." (Jurnal Modul, Vol. 11 No. 2, Agustus 2011).

Candrakirana, Rosita. "Penegakan Hukum Lingkungan Dalam Bidang Pengelolaan Sampah Sebagai Perwujudan Prinsip Good Environmental Governance Di Kota Surabaya." (Jurnal Yustisia, Edisi 93, September 2015).

Mutaqin dan Totok Heru TM. "Pengelolaan Sampah Limbah rumah Tangga Dengan Komposter Elektrik Berbasis Komunitas." (Jurnal Litbang Sekda DIY Biro Adm. Pembang, Vol. OI. II, No.2 Th 2010, ISSN 2085-9678). 
Mulasari, Surahma Asti, Adi Heru Husodo dan Noeng Muhadjir. "Kebijakan Pemerintah dalam Pengelolaan Sampah Domestik. Government Policy in Domestic Waste." (Jurnal Kesehatan Masyarakat Nasional Vol. 8 No. 8, Mei 2014).

Rizal, Mohamad. "Analisis Pengelolaan Persampahan Perkotaan (Studi Kasus Pada Kelurahan Boya Kecamatan Banawa Kabupaten Donggala oleh Mohamad Rizal." (Jurnal SMARTek, Vol. 9 No. 2. Mei 2011, hal. $155-172)$.

Undang-Undang Dasar 1945 dan Perubahannya.

Undang-Undang Pengelolaan Sampah, UU No. 18 Tahun 2008, TLN No. 4851, LN No. 69 Tahun 2008.

Undang-Undang Perlindungan dan Pengelolaan Lingkungan Hidup, UU No. 32 Tahun 2009, TLN No. 5059, LN No.140 Tahun 2009.

Peraturan Pemerintah Pengelolaan Sampah Rumah Tangga Dan Sampah Sejenis Sampah Rumah Tangga, PP No. 81 Tahun 2012, TLN No. 5347. LN No. 188 Tahun 2012 